\title{
Temporal Changes of Pyrite Oxidation Rate in Bolivian Sulphidic Mining Wastes
}

\author{
F. MóRICZ, F. MÁDAI \\ University of Miskolc, Faculty of Earth Science and Engineering, Institute of Mineralogy and Petrology, \\ moriczferi@gmail.com \\ University of Miskolc, Faculty of Earth Science and Engineering, Institute of Mineralogy and Petrology, \\ askmf@uni-miskolc.hu
}

Abstract. Since the 70's, when huge sulphidic open pits were developed, the acidic rock drainage (ARD) become the leader problem of the sulphidic mining industry. Although the recycling is an essential technology, it cannot cover the demand alone, thus mining activity needs to continue. Acidity in mine drainage commonly requires most of the attention, but the main problem is the caused elevated level of metal mobility and leaching, which are generated by the increased rates of sulphide weathering under acidic conditions. The Itos mine is a polymetallic vein deposit in Bolivia, had been mined for silver and tin until 1990, leaving behind much and huge tailings and mine waste heaps, where quite often the pyrite content exceeds $10 \%$. Serious ARD effects take place in the mine waste heaps. These processes can be well characterized with the $\mathrm{pH} 1$ or 2 of the seepage water, which forms serious alteration in the waste itself and the neighbouring rocks. In three consecutive years, the pyrite oxidation rate was investigated on the same 7 samples by humidity cell test. 5-6 months pauses were left between the humidity cell test periods, which mimics the alternation of wet and dry periods, typical for the place. The results give much more information, than the oxidation rate in the individual test periods, showing the changes by time. This applied method gave good result to characterize the behaviour of the waste in long-term. The column test was complemented with mineralogical analyses, such as electron probe micro analysis. The mineralogical and column test analyses show, that the changes of the pyrite oxidation rate split the samples into three different groups, one where the oxidation rate decreases, second where it increases with time and the third where oxidation rate is maximal and stays stable for several years.

Keywords: ARD, pyrite oxidation rate, behaviour in future, kinetic test, humidity cell test

\section{Introduction}

In the past two decades, the effect of acid rock drainage (ARD) has become the leading environmental problem in metal mining. Weathering starts to degrade sulphidic type ore, which is unstable on the surface environment, resulting low $\mathrm{pH}$ and mobilizes heavy metal contamination. The release of ARD to surface- and groundwater deteriorates the water quality and may cause depletion of alkalinity, acidification, bioaccumulation of metals, accumulation of metal in sediments, effects on habitats, elimination of sensitive species and unstable ecosystems.

Following the "nature pays principle", in the Itos mine, a polymetallic vein deposit was mined for silver and tin until 1990, giving one third of the world's silver production in the $19^{\text {th }}$ century [1][2], leaving 
behind a great number of huge tailings and mine waste heaps. Quite often, the pyrite content of the waste reaches or exceeds $10 \%$. Oxidizing sulphides produce serious acid rock drainage affects in Oruro, the mining town next to the mine waste heaps. These processes can be characterized by the $\mathrm{pH}$ 1 of the seepage water, which mobilizes heavy metals from the waste itself or the neighbouring rocks. [8]

In three consecutive years, the pyrite oxidation rate was investigated on the same seven samples by column test, which was complemented with mineralogical analyses (EPMA, XRPD). Five-to-sevenmonth pauses were left between the column test periods, which allow mimicking the alternation of wet and dry periods, typical of the climate of Oruro. Thus, the results give much more information than the oxidation rate for an individual column test period, showing the changes by time.

The column test shows that samples can be split by the changes of the pyrite oxidation rate into three different stages: where the oxidation rate shows increasing (marked type " $\mathrm{A}$ ") or decreasing tendencies (marked type " $\mathrm{C}$ ") or where the oxidation is maximal, so stable in the different years (marked type "B").

\section{Theoretical part and the samples}

As it was mentioned in the previous part, the problem is caused by the oxidation of iron sulphides mainly pyrite - when it reacts with water and oxygen at surface conditions as shown in equation (1). [6]

$$
\mathrm{FeS}_{2}+\mathrm{H}_{2} \mathrm{O}+\frac{7}{2} \mathrm{O}_{2} \rightarrow 2 \mathrm{SO}_{4}^{2-}+\mathrm{Fe}^{2+}+2 \mathrm{H}^{+}
$$

For investigating the oxidation rate of the samples, a special combination of humidity cell and column test methods was used. In the column test, experiments can be used to determine the kinetic behaviour of wastes when exposed to atmospheric weathering (sub-aerial storage), or stored under water cover (sub-aqueous storage). The advantage of the humidity cell test is that, primary reaction products are flushed out by rinsing water [3].

The main concept for the experiments was that using the column test, continuous airflow was pumped through the samples to maintain the maximal rate of pyrite oxidation. The through flowing air is more than the pyrite could use for its oxidization. In this way, the oxidation rate is controllable and maintained as maximal during the column test, so the process works like a "worst case scenario". In cyclic time periods, the samples were washed through and the seepage water was analysed for basic chemical parameters, anion and cation content.

Using equation (1), the pyrite oxidation rate could be determined in four different ways, such as 1) from the oxygen consumption, 2) the sulphate or 3) iron content and 4) from the $\mathrm{H}^{+}$, which defines the $\mathrm{pH}$. In this paper, pyrite oxidation rate was determined by inverse calculation from $\mathrm{pH}$, which could be easily and accurately measured, thus the $\mathrm{H}^{+}$content in the seepage could be determined correctly. Based on equation (1), it was shown that the correlation ratio between the pyrite and $\mathrm{H}^{+}$is $1: 2$, because each mole of pyrite results in 2 moles of acid. In the column test, $1000 \mathrm{~cm}^{3}$ destilled water was 
used for flushing, thus theoretically total oxidation of $59.99 \mathrm{mg}$ pyrite is needed for $1 \mathrm{dm}^{3}$ of $1 \mathrm{mmol} / \mathrm{l}$ $\mathrm{H}^{+}$content seepage.

The masses of the samples were premeasured, so for better comparison the results were calculated back to mass unit of oxidized pyrite for each kilogram of samples. For pyrite oxidation rate we use equation (2), to be determined from the measured $\mathrm{pH}$ of the rinse.

$$
R_{\text {pyox }}=\frac{10^{(-p H)} * \frac{p y_{m w}}{2} * V_{l} * \frac{7}{N_{d}}}{M_{s}}
$$

where $R_{\text {pyox }}$ is the pyrite oxidation rate (in unit of $g$ pyrite / week $/ \mathrm{kg}$ of sample), pymw is the molecular weight of pyrite $(119.98 \mathrm{~g} / \mathrm{mol}), V_{l}$ is the volume (in $\mathrm{dm}^{3}$ ) of the rinse, $N_{d}$ is time (in days) between rinsing the samples and $M_{s}$ is the mass (in $\mathrm{kg}$ ) of the sample.

The aim in the column test is to reach a steady state in the oxidizing system, which could mean stability in sulphate release rate, $\mathrm{pH}$ or other seepage water parameters. Previous studies and practice showed that in the case of fresh pyritic samples a year (easily even more time) is needed in the column to reach a steady state, while in the case of already oxidized samples this time is shorter, covering only some months (approximately 2-4 months).

Seven samples were collected by Ingar Walder in 2007 and 2008 in Itos mining district, Bolivia from the surface vadose-zone from approximately 10-30 cm depth of the waste heaps side walls, on which the column tests were completed. The samples represent different geotechnical and mineralogical scenarios (Table 1). From the point of geotechnical parameters and pyrite content, the sample Bol 1 and Bol 3 were similar. They were collected from the same waste heap, but from different parts. [5]

The maturation state of the sample, i.e. the residence time under field conditions will effect the time that is required to reach the steady state oxidation during the column test. The oxidation of fresh sample needs more time to start, as well as longer column test investigation to reach a steady state pyrite oxidation rate compared to the already oxidized samples.

In Oruro there were no strict mining regulations, thus the composition and the size of the waste dumps and tailing heaps are not known. The age is also uncertain, so we have no exact information about the residence time of these samples, except Bol 2, which is relatively fresh sample, because it stayed only 1-2 years as tailing. From visual, macroscopic and stereo microscopic observations we have an assumption, that the samples were stored about 15-25 years, but this is only a rough estimation.

In the three-year test period, the length of the column test was different for the individual years. The two Itos jig samples together with the Itos Granza samples underwent 3 years of analysis that means 101 days in the first one, 42 days in the second and 114 days in the third one. Whereas the three Bol samples had no column test analysis in the first year, so they underwent analysis only in the second (42 days) and third (114 days) years. 


\begin{tabular}{|l|c|c|c|c|}
\hline Sample & $\begin{array}{c}\text { Residence } \\
\text { time }\end{array}$ & Character & $\begin{array}{c}\text { Grain size / } \\
\text { main fraction }\end{array}$ & $\begin{array}{c}\text { Pyrite content } \\
\text { (from XRPD) }\end{array}$ \\
\hline Bol 1 & $15-25$ years & tailing & $2-15 / 3-5 \mathrm{~mm}$ & $2-3 \%$ \\
\hline Bol 2 & $1-2$ years & flotation tailing & $0.1-1 / 0.3-0.5 \mathrm{~mm}$ & $10-12 \%$ \\
\hline Bol 3 & $15-25$ years & tailing & $2-15 / 3-5 \mathrm{~mm}$ & $2-3 \%$ \\
\hline Itos jig 1 & $15-25$ years & jig tailing & $0.5-25 / 2-5 \mathrm{~mm}$ & $6 \%$ \\
\hline Itos jig 2 & $15-25$ years & jig tailing & $0.5-25 / 2-5 \mathrm{~mm}$ & $4 \%$ \\
\hline Itos Granza 1 & $15-25$ years & waste rock & $0.5-40 / 4-7 \mathrm{~mm}$ & $5 \%$ \\
\hline Itos Granza 2 & $15-25$ years & waste rock & $0.5-40 / 4-7 \mathrm{~mm}$ & $4 \%$ \\
\hline
\end{tabular}

Table 1. Physical parameters and pyrite content of the 7 samples analysed

\section{Analytical part and results}

Column tests provide information to characterize the pyrite oxidation rate. Additionally analytical methods were used for determination of the individual mineral phases and mineral alterations, such as XRPD was used for pyrite content analysis and SEM + EPMA for the definition of mineralogical composition and texture properties.

As it was already mentioned in the Theoretical part, the pyrite oxidation rate was determined by the $\mathrm{pH}$ value, based on equation (1) and (2). As a simple example, Figure 1 shows the pH values of the seepage water from the column test in the case of Bol 2 flotation tailing sample. Each year column test started with an up-running part, caused by the effect of the first flushes, where the secondary minerals, accumulated during the dry period were dissolved and washed out. After this quickly changing period, the $\mathrm{pH}$ has been stabilized, the stable $\mathrm{pH}$ refers to the pyrite oxidation. This $\mathrm{pH}$ changes tendency is well represented in Figure 1, where the data of the Bol 2 sample is shown. For the calculation, these stable periods were used, such as year 3 from day $21^{\text {st }}$ till day $114^{\text {th }}$.

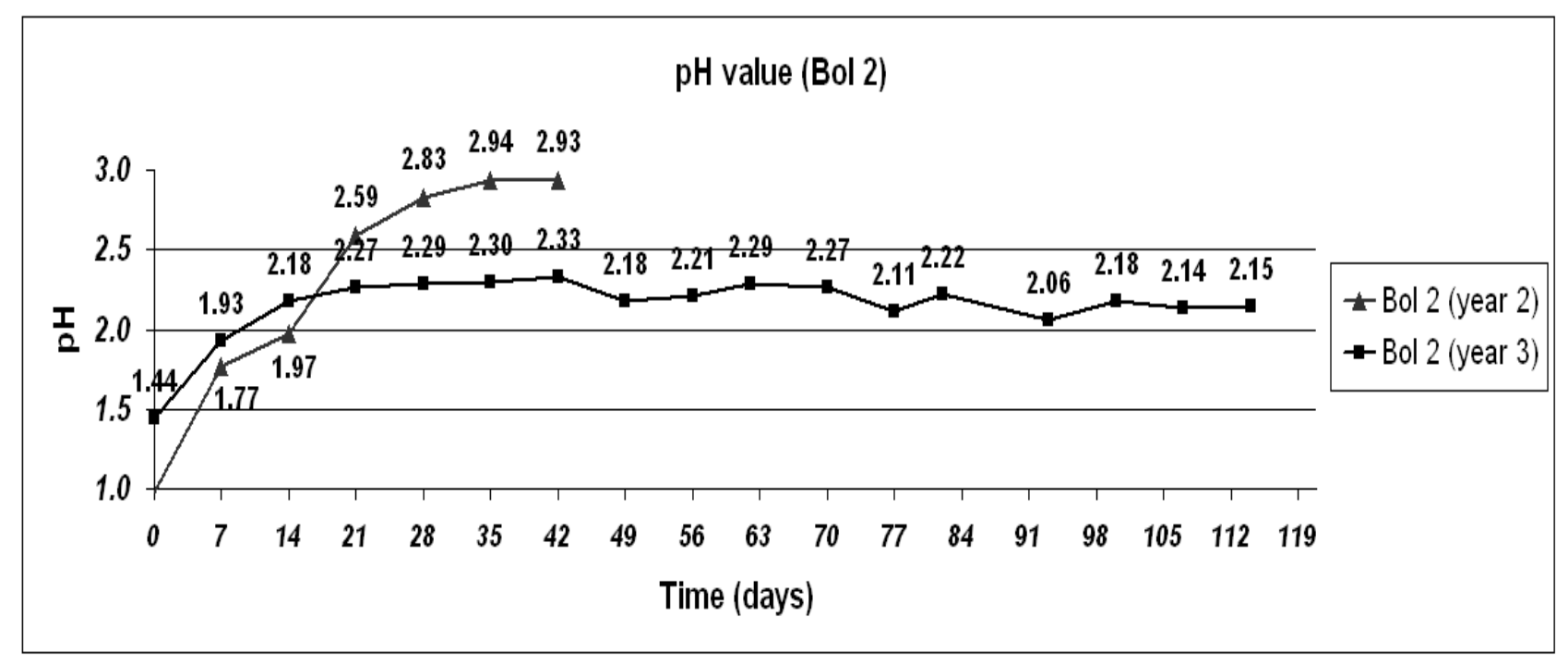

Figure 1. The $\mathrm{pH}$ changes of the sample Bol 2 during the investigation period 
In year 2 , when only 42 days ( 6 weeks) were available for running the tests, for the pyrite oxidation rate calculation, the $\mathrm{pH}$ values from the last 2-3 weeks were used. Figure 1 shows that even during this short time the $\mathrm{pH}$ became stable enough to do the oxidation rate calculations.

The following three figures show the changes in oxidation rate in the consecutive years. Figure 2 introduces the three samples called Bol 1, 2 and 3, Figure 3 shows the two Itos Granza waste rock samples while Figure 4 presents the two Itos jig tailing samples.

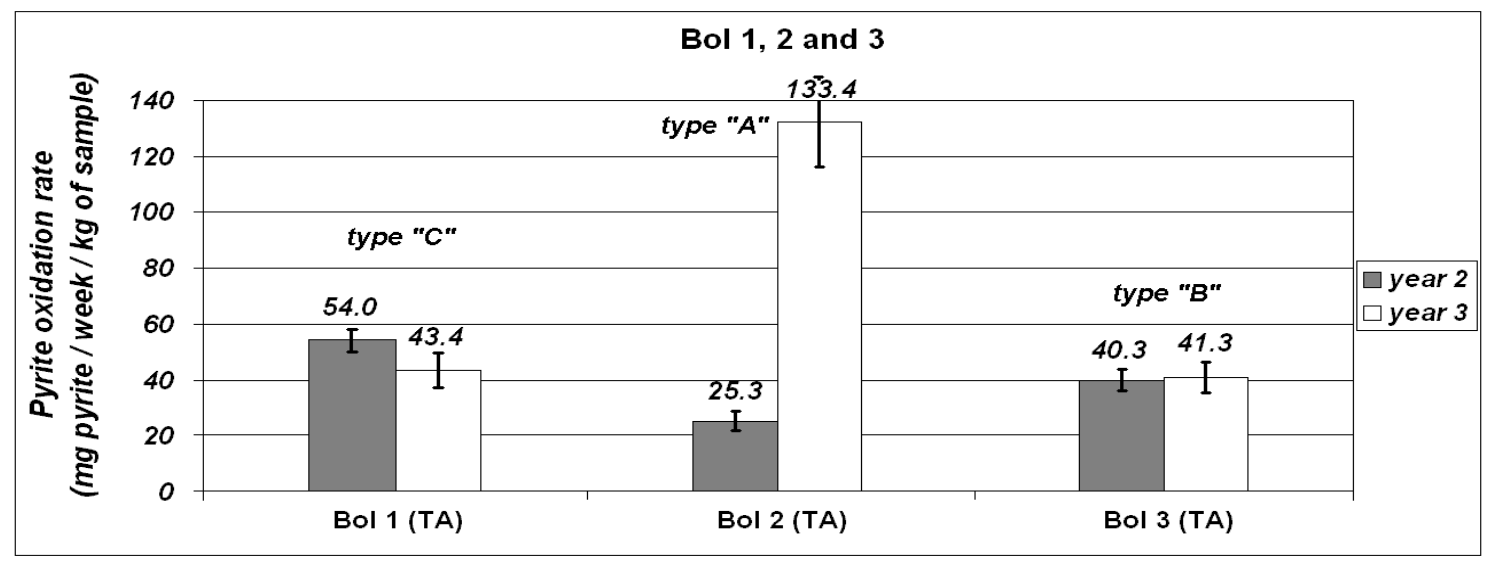

Figure 2. Changes of the pyrite oxidation rate in samples Bol 1, 2 and 3

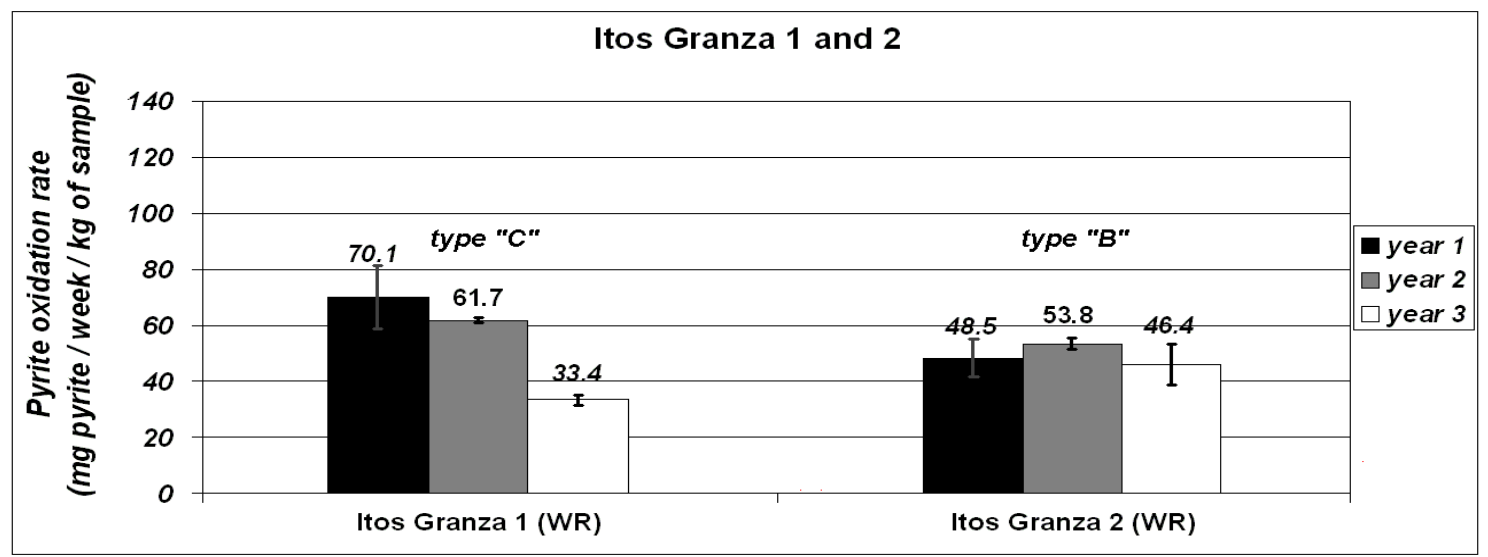

Figure 3. Changes of the pyrite oxidation rate in samples Itos Granza 1 and 2

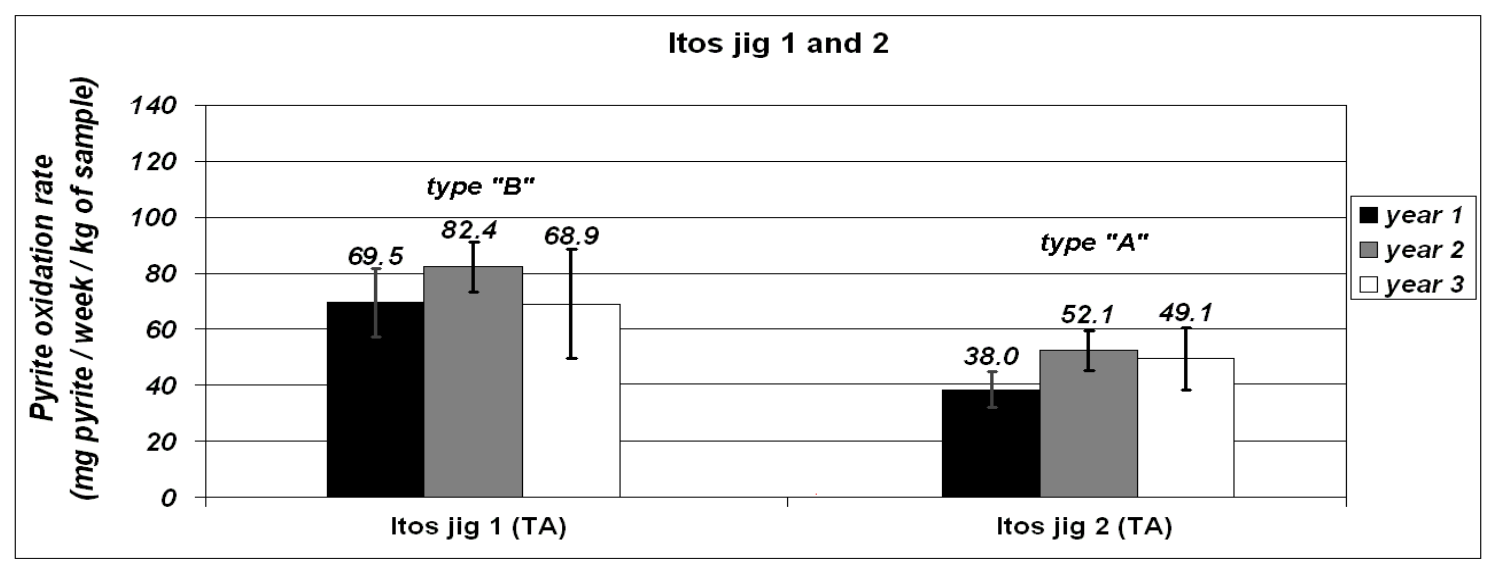

Figure 4. Changes of the pyrite oxidation rate in samples Itos jig 1 and 2 
To investigate the mineral alteration and pyrite oxidation, scanning electron microscope analyses were completed on samples before the column test, at Department of Mineralogy and Petrology, University of Miskolc. The SEM analysis also proved that the samples have already been strongly corroded. In addition to the primary minerals - such as quartz, pyrite, galena and cassiterite -, secondary sulphates (various types from the jarosite subgroup and gypsum), different iron oxihydroxides and oxides were found.

Intensive pyrite corrosion was detected both in tailings (Itos jig 1 and 2) and waste rock samples (Itos Granza 1 and 2) where the pyrite oxidation was usually complemented by formation of secondary iron sulphates. In Figure 5, a corroded pyrite (Py) crystal with cassiterite grains is shown from the sample Itos Granza 2. Strongly corroded pyrite (Py) particles with secondary iron sulphates are in Figure 6 from sample Itos Granza 1.The image of Figure 7 shows secondary gypsum formation on galena and pyrite crystals in samples Itos jig 1. [4]
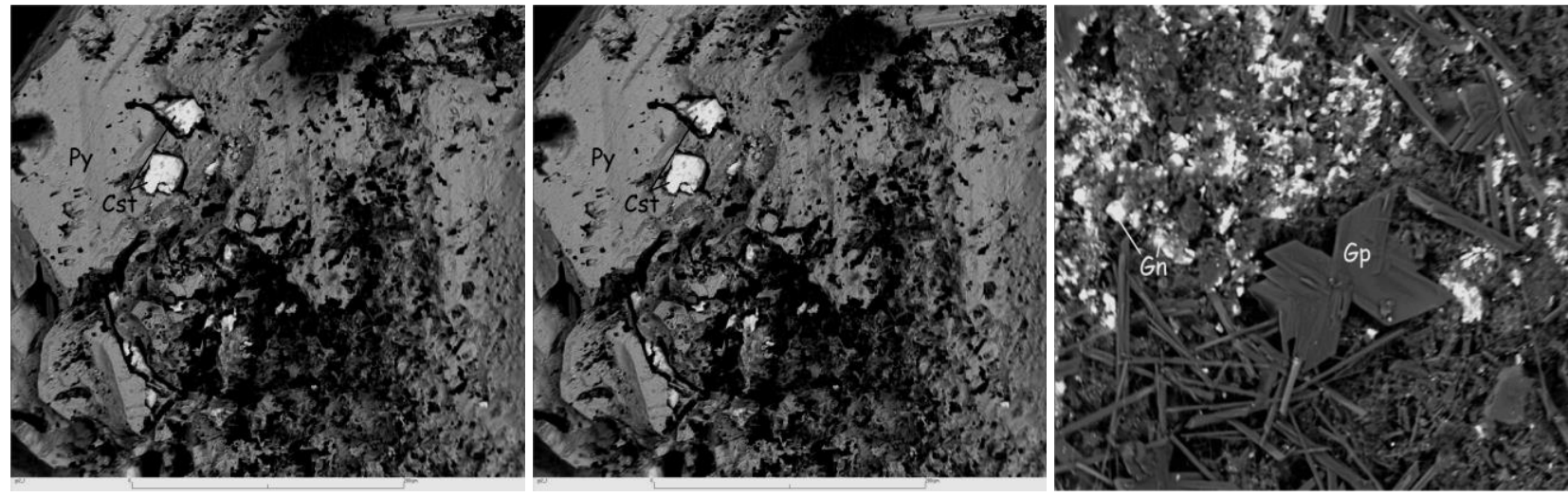

Figure 5. (left) Corroded pyrite with cassiterite in Itos Granza 2

Figure 6. (middle) Altered pyrite surface with iron sulphates in Itos Granza 1

Figure 7. (right) Well-developed twin gypsum crystal in Itos jig 1.

\section{Discussion}

Comparing the stabilized $\mathrm{pH}$ values, thus the pyrite oxidation rates for the consecutive test periods, the maturity of the samples could be assessed. The samples can be split into three different stages: fresh / weakly oxidized, premature / partly oxidized and mature / strongly oxidized. Other important indicators are the corrosion textures of pyrite and the appearing different secondary mineral groups. The following stages are distinguished:

In the weakly oxidized stage (marked type " $A$ ") the pyrite oxidation rate is increasing in the consecutive years. Samples Bol 2 (Figure 2) and Itos jig 2 (Figure 4) are good representations of this type of behaviour. In the beginning oxi-hydroxide minerals appear as alteration products after the sulphides. Then the $\mathrm{pH}$ goes below 2-2.5, so the oxi-hydroxide minerals dissolve back and under such a low pH only sulphate minerals are formed, such as jarosite, melanterite or gypsum. The increase in pyrite oxidation rate means that in the future the reactions will become faster. Because of the low $\mathrm{pH}$ and speeding up of the reactions, the heavy metal mobility increases. 
Partly oxidized stage (marked type "B") covers the samples Bol 3 (Figure 2), Itos Granza 2 (Figure 3) and Itos jig 1 (Figure 4), where the pyrite oxidation is maximal, thus stable - changes only within a few percentage - in the different years. The maximal pyrite oxidation rate also means that this stage has the lowest $\mathrm{pH}$, which keeps for longer time. In the beginning of this stage still the sulphate minerals will be the dominant secondary phases, but in the end of the stage as the pyrite oxidation rate starts decreasing and the $\mathrm{pH}$ increasing, beside the sulphates, some oxi-hydroxide minerals can appear.

Strongly oxidized stage (marked type "C") includes the samples Bol 1 (Figure 2) and Itos Granza 1 (Figure 3), where the pyrite oxidation rate is decreasing in consecutive years. The reaction rate slows down, thus the $\mathrm{pH}$ continuously increasing, but not as steep as the decreasing was in the first stage. The slow increase of $\mathrm{pH}$ in this phase is due to pyrite being excused. Bulk oxidation rate becomes lower due to less pyrite available.

Beside the determination of the three differentiated stages, on those samples which are in the "Partly oxidized stage", thus the sample Bol 3, Itos Granza 2 and Itos jig 1, further establishment was done. In this stage the pyrite oxidation rate is stable in the consecutive years, thus the oxidation itself does not change in function of time, at least for several years. Average of the pyrite oxidation rates from the consecutive years were calculated, which were divided by the pyrite content of the samples. In case of the three samples, between the pyrite oxidation rate and the pyrite content linear correlation was defined (Figure 8). For those Bolivian samples, which are in "Partly oxidized stage", calculated to $1 \mathrm{~kg}$ of sample, every percentage of pyrite means apx. 12-13 mg of pyrite oxidation weekly.

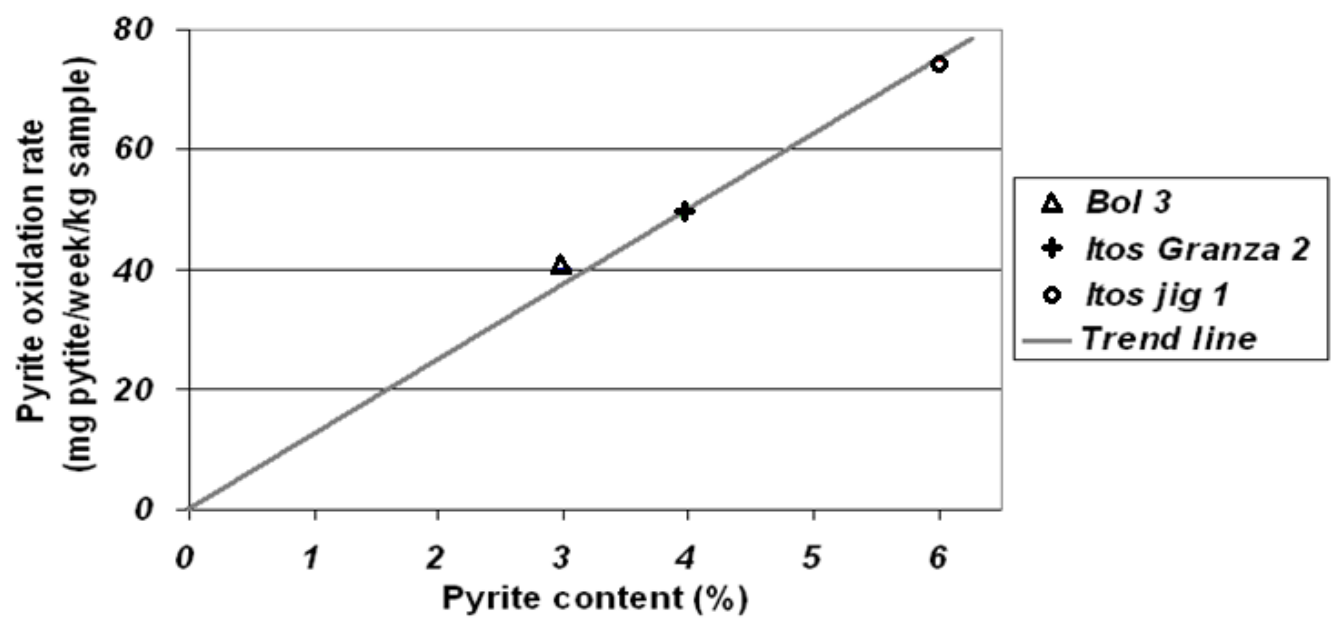

Figure 8. Correlation between oxidation rate and pyrite content.

\section{Conclusion}

The three stages shown above are members of a natural progression for weathering of iron sulphide containing tailings and waste rocks. The oxidation of the fresh material starts with increasing rate, then with time the reaction rate becomes stable, and finally decreases. The complete process looks like a bell shaped curve as it is shown on Figure 9, where a theoretical pyrite oxidation curve is present. The graph is illustrating waste rocks were there is no or little neutralising / buffering reactions, such as massive sulphide deposits and polymetallic veins like the Itos deposit. 
This three-year-long investigation indicated the maturity of the tailings and waste materials. Table 2 gives an overview of the different oxidation rate stages of the samples. The three stages define also the rates of the emitted pollution and heavy metal mobility.

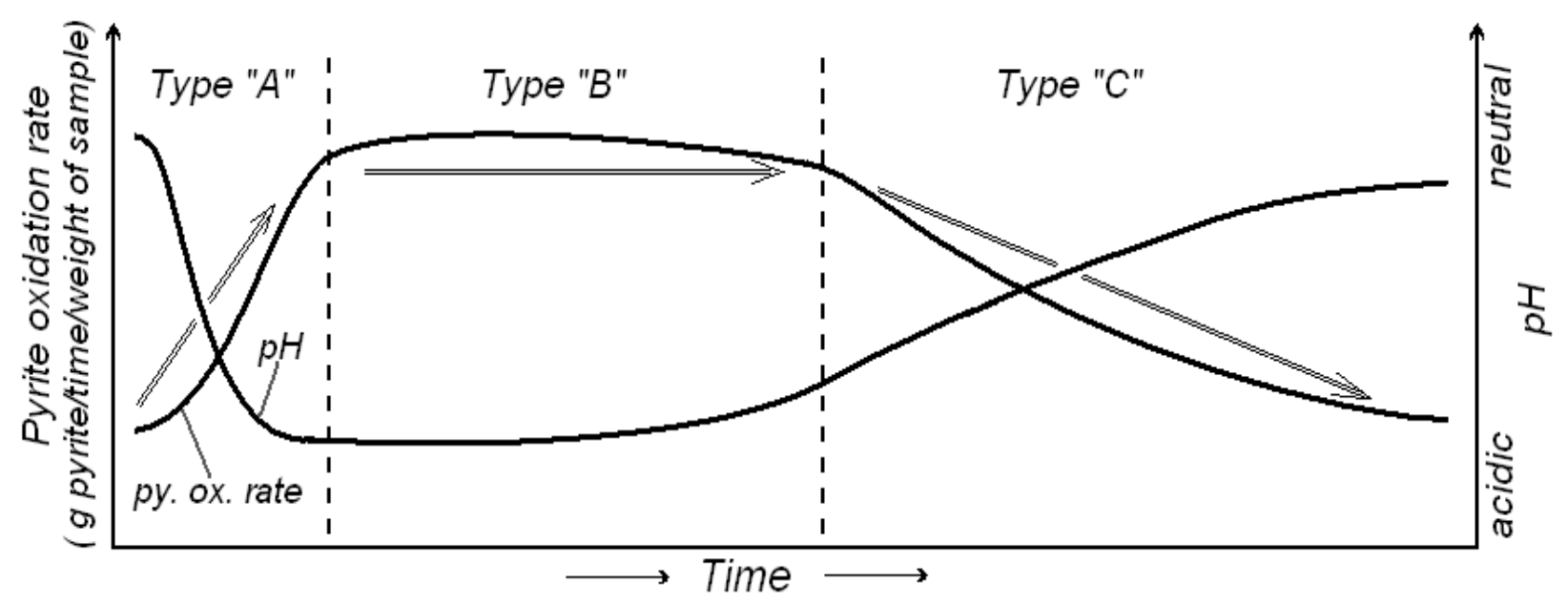

Figure 9. Pyrite oxidation changes in function of a long term process (after [7])

In the first - type " $A$ " - stage the pollution and heavy metal content will increase with time. The material in this stage needs correct waste management and appropriate handling. If the material is in the middle stage, the oxidation and the heavy metal mobility are at the maximum, as the $\mathrm{pH}$ is the lowest in this stage. In this stage at least controlling and monitoring is required. The third, the strongly oxidized stage means that the tailing or waste rocks are already after the peak pollution. The material in this stage is stable enough not to be able to cause any environmental problem. The slowing down reactions ensure that the heavy metal mobility decreases as the $\mathrm{pH}$ increases. The normalizing $\mathrm{pH}$ controls mineral alteration, as iron oxi-hydroxides and oxides are produced. Finally a gossan type mineralization could be formed as a cover on the waste.

\begin{tabular}{|l|c|c|}
\hline \multicolumn{1}{|c|}{ Sample } & $\begin{array}{c}\text { Oxidizing } \\
\text { stage }\end{array}$ & Behaviour in the future \\
\hline $\begin{array}{l}\text { Bol 2 } \\
\text { Itos jig 2 }\end{array}$ & weakly & $\begin{array}{r}\text { increasing in pollution and heavy metal mobility, decreasing } \mathrm{pH} ; \\
\text { pollution peak in the future, further problems; } \\
\text { the situation calls for management }\end{array}$ \\
\hline $\begin{array}{l}\text { Bol 3 } \\
\text { Itos jig 1 } \\
\text { Itos Granza 2 }\end{array}$ & partly & $\begin{array}{r}\text { stable low pH, maximal pollution and heavy metal mobility; } \\
\text { pollution peak at present, problems will not increase, but stays for an } \\
\text { uncertain time; monitoring is required }\end{array}$ \\
\hline $\begin{array}{l}\text { Bol 1 } \\
\text { Itos Granza 1 }\end{array}$ & strongly & $\begin{array}{c}\text { decreasing pollution and heavy metal mobility, increasing } \mathrm{pH} ; \\
\text { pollution peak in the past, no further increasing problems; } \\
\text { monitoring is not required }\end{array}$ \\
\hline
\end{tabular}

Table 2. Overview of the behaviour in the future

\section{Acknowledgement}

"The described article/study was carried out as part of the EFOP-3.6.1-16-2016-00011 "Younger and Renewing University - Innovative Knowledge City - institutional development of the University of Miskolc aiming at intelligent specialisation" project implemented in the framework of the Szechenyi 
2020 program. The realization of this project is supported by the European Union, co-financed by the European Social Fund."

\section{References}

[1] Chance F.M. (1948/a), Tin-silver veins of Oruro, Bolivia /Part1/. Economic Geology Vol. 43, No.5, 333-383.

[2] Chance F.M. (1948/b), Tin-silver veins of Oruro, Bolivia /Part2/. Economic Geology Vol. 43, No.6, 435-470.

[3] Lapakko K. (2003), Developments in humidity-cell tests and their application. In Jambor JL, Blowes DW, Ritchie AIM (eds): Environmental aspects of mine wastes. Mineralogical Association of Canada, Vol.31, 147-164.

[4] Móricz F., Walder I., and Mádai F. (2009), Geochemical and Mineralogical Characterization of Waste Material from the Itos Sn-Ag Deposit, Bolivia. $8^{\text {th }}$ ICARD Proceedings.

[5] Móricz F., Walder I., and Mádai F. (2010), Kinetic testing and mineralogical characterization of sulphide mine waste from the Oruro deposit (Bolivia). 20 th IMA General Meeting

[6] Nordstrom, D. K. (1982), Aqueous pyrite oxidation and the consequent formation of secondary iron minerals. - In: Kittrick, J.A., Fanning, D.S. and Hossner, L.R. (eds.): Acid Sulfate Weathering. Soil Sci. Soc. Am., 37-56.

[7] Ritchie AIM (1994): The waste-rock environment. In Jambor JL and Blowes DW (eds.): Environmental Geochemistry of Sulfide Mine-Waste, Mineralogical Association of Canada. Vol. $22,201-244$.

[8] Walder I., Victoria J., Boon R.G.J., Walder P. (2010), Characterization and mitigation of the Ag-Sn San Jose Mining District, Bolivia. 20 th IMA General Meeting. 